\title{
Electrical Characterization of Titanium Dioxide Nanotubes Using Dielectric and Electrochemical Impedance Spectroscopy
}

\author{
VERONICA MANESCU (PALTANEA), GHEORGHE PALTANEA*, IOSIF VASILE NEMOIANU, DORINA POPOVICI, \\ RADU MIRCEA CIUCEANU \\ University Politehnica of Bucharest, Electrical Engineering Department, 313 Splaiul Independentei, 060042, Bucharest, Romania
}

\begin{abstract}
The paper is devoted to the electrochemical anodizing method for TiO, nanotube layers generation on titanium surface. It is commonly accepted that parameters like anodizing time, electrical voltage and the actual type of electrolyte are important factors in what concerns the TiO nanotube diameters and their surface density. The present study considers self-organized titanium nanotubes resulted from an aqueous solution of $49.5 \mathrm{wt} \% \mathrm{H}_{2} \mathrm{O}, 49.5 \mathrm{wt} \% \mathrm{glycerol}, 1 \mathrm{wt} \% \mathrm{HF}$ used as the electrolyte. The actual anodizing duration was 8 hours at an applied voltage of $25 \mathrm{~V}$. Through the technique of scanning electron microscopy, it is shown that the resulted tubular nanostructure is one-dimensional having an approximate inner and outer diameters of $90 \mathrm{~nm}$ and $110 \mathrm{~nm}$, respectively. From an electrical point of view, the analysed materials properties were determined using electrochemical and dielectric impedance spectroscopy tests.
\end{abstract}

Keywords: titanium nanotubes, electrochemical impedance spectroscopy, dielectric spectroscopy

The vertically oriented $\mathrm{TiO}_{2}$ nanotube (NT) arrays obtained through potentiostatic anodization of titanium present a large internal surface area material organization, and, at the same time, a structural geometrical order. The vectorial charge transfer between interfaces benefits from the fact that the rigorously oriented nanotubes array represents very efficient electron percolation pathways. It has been proven that $\mathrm{TiO}_{2}$ nanotube arrays exhibitexcellent charge transport and carrier lifetime characteristics allowing their use in a large spectrum of practical hightech applications, such as: sensing devices, dye-sensitized solar cells, water photoelectrolysis hydrogen production, high-capacity electrochemical capacitors and $\mathrm{CO}_{2}$ photocatalytic reduction under sunlight exposure. Last but not least, the nanotube arrays have found application in the area of biomedicine, to mention just targeted drug delivery, tissue fabrication, biosensing, molecular filtration, etc. [1].

In literature there are described quite numerous $\mathrm{TiO}_{2}$ nanotubes fabrication processes, from which ${ }^{2}$ electrochemical anodizing stands out because it makes nanotube dimensions more controllable [2"5] in a less expensive way, in comparison with other methods such as generation based on nanoporous alumina template [6"8], sol-gel processes [9, 10] and hydrothermal procedures [11, 12].

The main properties of the one-dimensional titanium nanotube arrays are: thickness of the walls, wall roughness, tube length, pore diameter, and tube - to - tube distance.

Generally, there are two main operation parameters, which affect the porous layers structure and morphology. First, the electrochemical parameters (mostly voltage of anodization) and, secondly, the parameters of the solution (such as electrolyte $\mathrm{pH}$, water content, and $\mathrm{HF}$ concentration). Finally, temperature and anodizing time are also parameters to be taken into account $[13,14]$. The desired practical application imposes an optimum on the $\mathrm{TiO}_{2}$ nanotube structure. For instance, the state of the oxide films on Ti is known to be amorphous at low voltages (below $20 \mathrm{~V}$ [15]). Crystalline state is the result of higher voltages. Moreover, in literature the anodizing parameters are proven to determine the crystal state, namely to be anatase, a mixture of anatase and rutile, or just rutile [13, $16,17]$. The crystalline anatase state is characterized by superior mechanical strength of the material. Also, the length of the tubes is determined by the $\mathrm{pH}$ of the electrolyte solution. Non-aqueous electrolytes determine a better order of the nanotube array with a reduced heterogeneity of the side walls [18]. The anodization time parameter is important because exceeding a certain duration it shortens the nanotubes length through dissolution-induced cleaving [19]. The applied voltage is directly proportional to the diameter of the nanotube as a result of an ionic current appearing over a limit value [20, $21]$. The type of electrolyte is responsible for the rate of pore size [22].

Anodization process and different ways of $\mathrm{TiO}_{2}$ growth

Anodization represents an electrolytic procedure covering a metallic surface with a protective or decorative oxide film [1]. The anodization process leads to increasing both the thickness and density of the oxide layer appearing always on the surface of metals as the result of air exposure. It is commonly known that metal oxides $\left(\mathrm{MO}_{\mathrm{x}}\right)$ dissolve in part in electrolytes. Therefore, the use of an electrolyte presenting an oxide forming rate superior to its dissolving rate is necessary [1]. Fluoride ions presence in electrolytes, along with specific anodization conditions (temperature, electric potential), constitute a different growth morphology that can be mentioned. Ordered $\mathrm{TiO}_{2}$ nanotubular or nanoporous structures of some other oxides of transition metal can be formed, using electrolytes containing $\mathrm{F}$ - ions $[1,13]$.

As mentioned before, the growth of compact oxides, representing the initiation of the nanotubes formation process, is a trade-off between two opposing reactions. On one hand anodic oxide formation eq. (1), and on the other hand, chemical dissolution of the oxide as soluble fluoride complexes eq. (2) [1]:

$$
\begin{aligned}
& \mathrm{Ti}-4 \mathrm{e}^{-}+2 \mathrm{H}_{2} \mathrm{O} \rightarrow \mathrm{TiO}_{2}+4 \mathrm{H}^{+} \\
& \mathrm{TiO}_{2}+6 \mathrm{~F}^{-} \rightarrow\left[\mathrm{TiF}_{6}\right]^{2-}+2 \mathrm{O}^{2-}
\end{aligned}
$$

* email: gheorghe.paltanea@upb.ro; paltanea03@yahoo.com 
As a result, the metal surface (the anode) is gradually covered by compact oxides and the formation of nanotubes begins. Direct complexation occurring at the interface between the oxide and the electrolyte is described by reaction (3) [1]:

$$
\mathrm{Ti}^{4+}+6 \mathrm{~F}^{-} \rightarrow\left[\mathrm{TiF}_{6}\right]^{2-}
$$

If the electrolyte does not contain fluoride, reaction (1) describes the growth of the oxide layer deposited on the anodized titanium surface, as shown in figure 1.a. Figure 1.b shows the more complex electrolysis reaction taking place when fluoride ions are involved. The process complexity appears as a result of two effects of the fluoride ion: (a) the possibility of forming water-soluble $\left[\mathrm{TiF}_{6}\right]^{2-}$ complexes as described by reaction (2), and (b) the diminishing of ionic radius, allowing them easily to attach to the growing TiO structural lattice and to be carried across the oxide by the applied electric field (thus competing with $\mathrm{O}^{2-}$ transport). A permanent chemical dissolution of the $\mathrm{TiO}_{2}$ layer appears because of the complex, which prevents $\mathrm{Ti}(\mathrm{OH}) \mathrm{O}$ oxyhydroxide precipitation. In the oxide/solution interface, the generated $\mathrm{Ti}^{4+}$ ions, will be solvated to (reaction (3)) before a reaction is initiated with the $\mathrm{Ti}(\mathrm{OH})_{x} \mathrm{O}_{y}$ precipitate layer [13].

The chemical dissolution of $\mathrm{TiO}_{2}$ appears through the tube length, thus, over an extended time, the nanotubes become V-shaped, with the tube tops having significantly thinner walls than tube bottoms [13, 23, 24]. In literature, the cause for tube formation on titanium surface, in contrast with a nanoporous structure, is not yet totally demonstrated, but some authors associated it with the accumulation of fluoride species at the tube bottom, and thus it results in a weaker (and more soluble) TiO, structure between pore and tube structures [13, 16, 18, 22].

\section{Experimental part}

Synthesis of $\mathrm{TiO}_{2}$ nanotubes

We used titanium (99.7\%) from Alfa Aesar. The samples have been cut circular with a diameter of disk equal to 30
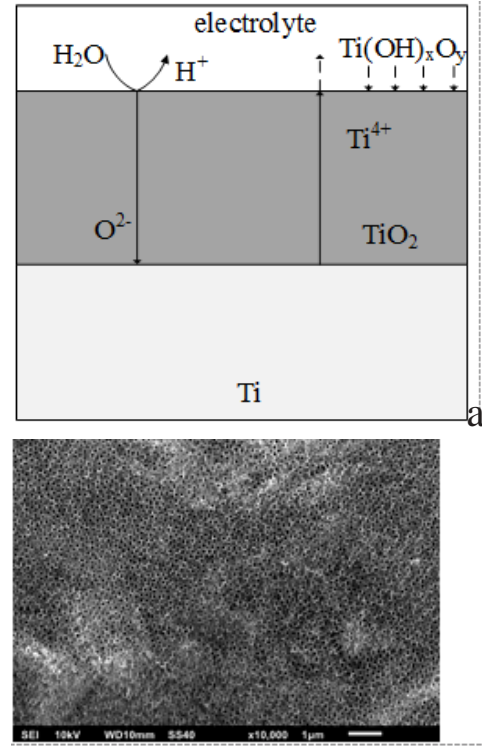

a)

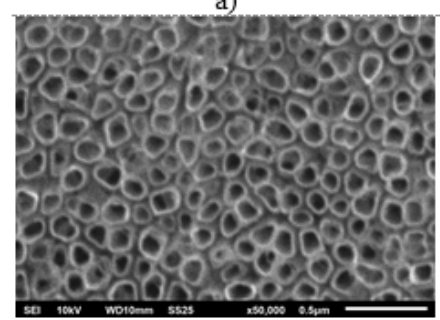

c)
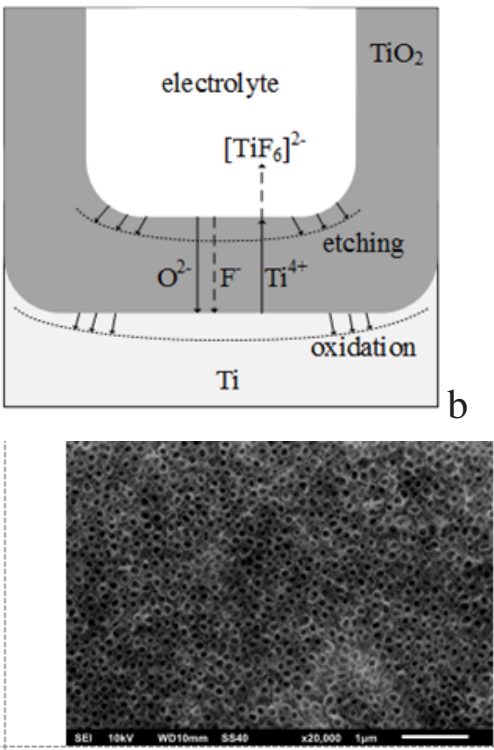

b)

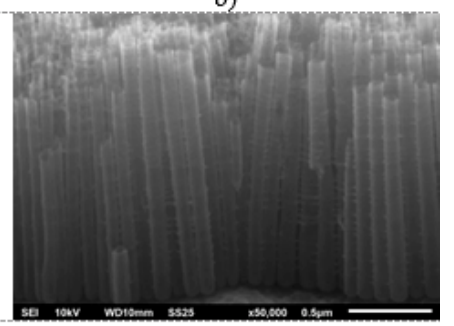

d)

REV.CHIM.(Bucharest) $69 \diamond$ No. 12 2018 $\mathrm{mm}$ and $0.5 \mathrm{~mm}$ thickness. In order to obtain $\mathrm{TiO}_{2}$ nanotubes, firstly the samples were cleaned according to the following steps: (1) polishing with $240 \div 2000$ grit sand paper, (2) sonication in 50:50 VN ethanol-water solution, for $1 \mathrm{~min}$ at $18 \mathrm{kHz}$ and (3) cleaning with distilled water.

The electrochemical setup consisted of a DC power supply and an electrode (graphene cathode and titanium sample as anode) cell filled with an aqueous solution of 49.5 wt $\% \mathrm{H}_{2} \mathrm{O}-49.5 \mathrm{wt} \%$ glycerol $-1 \mathrm{wt} \% \mathrm{HF}$. A $25 \mathrm{~V}$ DC voltage has been applied for 8 hours, at room temperature. After that, the specimen was sonicated for $1 \mathrm{~min}$ at a frequency of $18 \mathrm{kHz}$ to remove the electrolyte.

A scanning electron microscope, model Zeiss Supra 35 VP, with Schottky electron field emission and secondary electron imaging mode was used to prove that $\mathrm{TiO}_{2}$ nanotubes were formed at the surface of the probe (fig. 2).

The average inner and outer diameters of the $\mathrm{TiO}_{2}$ nanotubes were measured using Smart SEM User Interface Software. It was noticed that the average value of the inner diameter was approximately equal to $D_{\text {int }}=90 \mathrm{~nm}$, and for the outer diameter was found a mean value of $D_{\text {ext }}=110$ $\mathrm{nm}$. Also, the average length of the nanotubes was $h=$ $1000 \mathrm{~nm}$ and the distance between nanotubes $d=10 \mathrm{~nm}$.

\section{Electrical characterization}

The semiconducting properties of the $\mathrm{TiO}_{2}$ tubes were up to now described mainly for pure $\mathrm{TiO}_{2}$ in terms of their photo-response [13, 25-29] and their capacitance behaviour (Mott-Schottky plots) [13, 28-31]. In order to investigate the nanotubular layer impedance an electrochemical device (Solartron SI 1287) and a frequency analyser (Solartron 1250) were also used over frequency range $0.1 \mathrm{~Hz}$ to $65 \mathrm{kHz}$, in potentiostatic conditions. The electrode potentials were measured against a saturated calomel reference electrode (SCE) in the range ( $0.1 \mathrm{~V} / \mathrm{SCE}$ to $-0.7 \mathrm{~V} / \mathrm{SCE}$ in $100 \mathrm{mV}$ steps), by using a $10 \mathrm{mV}$ sinusoidal potential modulation. The surfaces of the working electrode were isolated with epoxy resin. To make possible the electric contact, a copper conductor was attached to
Fig. 1. Titanium anodization: (a) in $\mathrm{H}_{2} \mathrm{O}$ electrolyte (resulting flat layers); (b) in F- electrolyte (resulting nanotube growth) [13]

Fig. 2. SEM images of the $\mathrm{TiO}_{2}$ nanotubes growth on titanium, using secondary electron emission at: a) $\times 10000$; b) $\times 20000$; c) $\times 50000$ frontal views and d) $\times 50000$ lateral view magnification scales 
the sample. All the measurements were done in $1 \mathrm{~mol} \mathrm{~L}^{-1}$ $\mathrm{Na}_{2} \mathrm{SO}_{4}$ solution using deionised water.

The electrical characterization of the sample was also performed through Broadband Dielectric Spectroscopy (BDS) in the frequency range from $0.1 \mathrm{~Hz}$ to $1 \mathrm{MHz}$, using Alpha-N Frequency Response Analyser and a 1200 BDS parallel-plate capacitor with two gold-plated electrodes provided by Novocontrol Technologies (Germany). The amplitude of the time-varying applied voltage was kept constant at $1 \mathrm{~V}$. The dielectric cell was electrically shielded and both instruments were interfaced to a PC for simultaneous control and data acquisition. Experimental data were analysed through electrical conductivity, electrical resistivity, and impedance.

\section{Results and discussions}

Geometrical parameters and electrical capacitance of the $\mathrm{TiO}_{2}$ nanotubes

As presented in [32-34] the geometrical parameters were identified (fig. 3). It was assumed that the $\mathrm{TiO}_{2}$ NTS were disposed in an ideal hexagonal regular network of identical and equally spaced structures. The nanotubes were considered as hollow cylinders with the internal and external diameters $D_{\text {int }}$ and $D_{\text {ext' }}$ measured through SEM investigation.

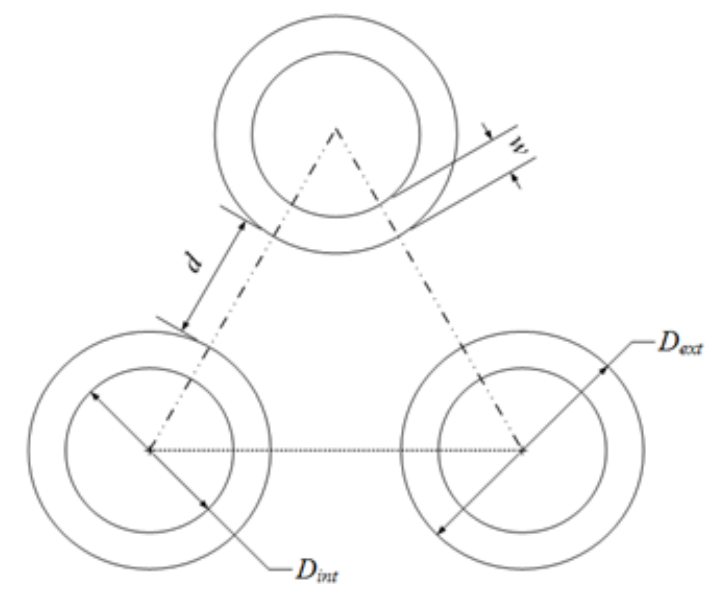

Fig. 3. Schematic arrangement to describe the ideal hexagonal regular network ( $1 / 6$ from the entire structure) of the nanotubes layer

The wall thickness $w$ was computed as it follows:

$$
w=\frac{D_{\text {ext }}-D_{\text {int }}}{2}
$$

The length $h$ of the nanotubes and the distance $d$ between two tubes are supposed to be kept constant. The solid fraction ö was considered as the ratio of the surface area that forms the NTs, with respect to the total surface area, which includes the circular openings and the intertube voids). Also, a geometrical roughness factor $H$ was computed as the ratio of inner, outer, flat top, bottom surface of tube array in relationship with the corresponding projected area [32, 33]:

$$
\begin{aligned}
& \varphi=\frac{\pi}{2 \sqrt{3}} \frac{D_{e x t}^{2}-D_{i n t}^{2}}{\left(D_{e x t}+d\right)^{2}} ; \\
& H=\frac{2 \pi h\left(D_{e x t}+D_{i n t}\right)}{\sqrt{3}\left(D_{e x t}+d\right)^{2}} .
\end{aligned}
$$

Based on the ideal hexagonal model, the density of nanotubes $N_{-}$(number of tubes per unit area) and total developed surface $S_{T}$, can be calculated as:

$$
\begin{aligned}
& N_{T}=\frac{2}{\sqrt{3}\left(D_{\text {ext }}+d\right)^{2}}, \\
& S_{T}=H S_{\text {sample }},
\end{aligned}
$$

where in our case $S_{\text {sample }}=706.5 \mathrm{~mm}^{2}$

The nanotubular layyer is not a flat electric capacitor. Electrical voltage detected between the nanotube walls and the space charge zone is distributed in a circular way over a few nanometers [34,35]. The electrons' transport is directly affected by the wall thickness because in the wall middle can appear a neutral region, if the width of the space charge zone is lower than the half of the wall thickness. Generally, in the tubular structure, the space charge zone extends circularly in the side walls of the tubes. Considering that the band bending can be described within a half-tube wall and, if the Poisson equation is considered in cylindrical coordinates, the space charge layer capacitance $C$, over the tube surface wall unit, can be express as [36]:

$$
C=\frac{\varepsilon \varepsilon_{0}}{2\left(\frac{D_{\text {ext }}+D_{\text {int }}}{4}\right) \ln \frac{\frac{D_{\text {ext }}+D_{\text {int }}}{4}-x}{D_{\text {int }} / 2}},
$$

where $x$ is the maximum value of the half width of the wall thickness $w$ (total depletion is determined in the case of $x=0$ ), the dielectric constant is $\varepsilon=100$ for TiO, NT and $\varepsilon_{0}=8.854187 \times 10^{-12} \mathrm{~F} / \mathrm{m}$ is the vacuum permittivity. The minimum value of this capacitance could be considered for $x=0$ [32].

The TiO NT geometrical parameter values are presented in table 1.

It can be noticed an increase of the space charge layer capacitance directly proportional to the value $x$ (fig. 4), for $x$ less than $4 \mathrm{~nm}$. The maximum computed value was equal to $400 \mu \mathrm{F} / \mathrm{m}^{2}$, determined for $x=w / 2$ and the minimum value was $8.392 \mu \mathrm{F} / \mathrm{m}^{2}$.

\section{Analysis of the $\mathrm{TiO}_{2}$ NTs electrical parameters by} impedance spectroscopy

Electrochemical impedance spectroscopy (EIS) was used in order to determine the kinetic parameters of different materials. It is based on the changes of electrochemical cell impedance represented by interfaces of metal electrodes [37, 38], immersed in an electrolyte.

\begin{tabular}{|l|l|l|l|l|l|l|l|l|c|}
\hline $\begin{array}{l}D_{\text {int }} \\
{[\mathrm{nm}]}\end{array}$ & $\begin{array}{l}D_{\text {ext }} \\
{[\mathrm{nm}]}\end{array}$ & $h[\mathrm{~nm}]$ & $d[\mathrm{~nm}]$ & $w[\mathrm{~nm}]$ & $\varphi$ & $H$ & $N_{\mathrm{I}}\left[\mathrm{cm}^{-2}\right]$ & $S_{\mathrm{T}}\left[\mathrm{cm}^{2}\right]$ & $\begin{array}{c}C_{(x=0)} \\
{\left[\mu \mathrm{F} / \mathrm{m}^{2}\right]}\end{array}$ \\
\hline 90 & 110 & 1000 & 10 & 10 & 0.251 & 50.383 & $0.8 \times 10^{10}$ & 35.595 & 8.392 \\
\hline
\end{tabular}

Table 1

GEOMETRIC PARAMETERS OF THE TiO NANOTUBULAR ARRAY 


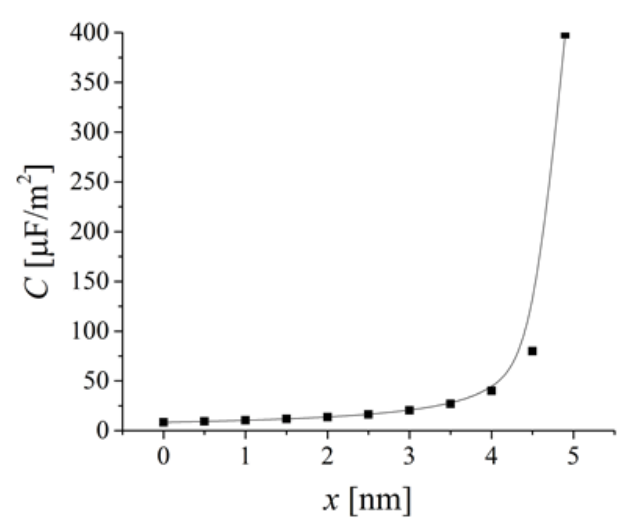

Fig. 4. Space charge layer capacitance per surface of tube wall as a function of the distance from the middle of the wall

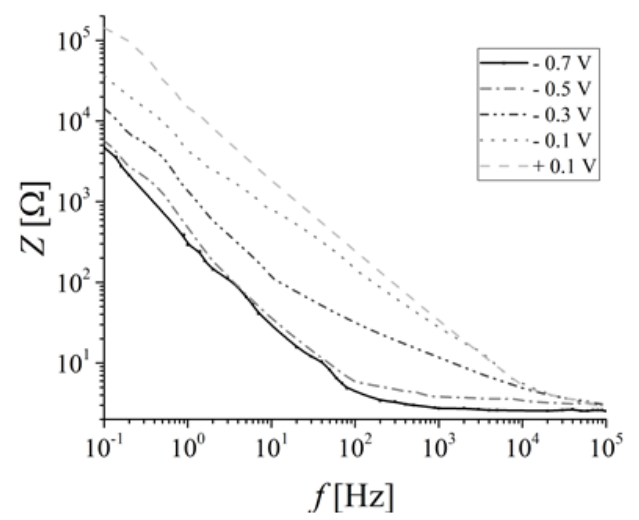

Fig. 5. Bode representation of the impedance variation in the case of different applied potentials

In figure 5 is presented the impedance spectra in Bode representation, for different applied potentials between $0.7 \mathrm{~V}$ and $0.1 \mathrm{~V}$. It can be observed a decrease of the electrical impedance modulus by shifting the value of the potential towards positive, which puts in evidence a decrease in the resistance of electron transfer and thus an increase of the electron flow through the space charge region, when the potential gets close to the conduction band.

Figure 6 shows the variation of the space charge capacitance as a function of the applied voltage. With more positive values of the applied potential, the capacitance value increases, a fact that can be explained as a result of the width diminution of the space charge layer when the potential is around the conduction band value.

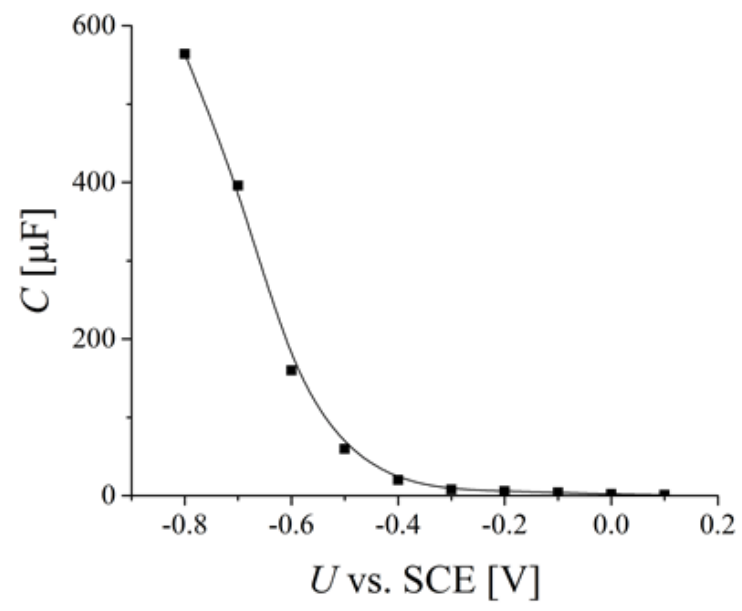

Fig. 6. Space charge layer capacitance as a function of the applied voltage referred to an SCE potential
In the case of BDS analysis [39, 40], the behaviour of $\mathrm{TiO}_{2}$ nanotube sample, located between the round plate electrodes of the capacitor, can be considered as an equivalent electrical circuit composed of a capacitance, $C(\omega)$, in parallel with a resistance, $R(\omega)$; $\omega$ is the angular frequency. The outputvalues of the analyser are associated with the complex impedance $Z_{s}(\omega)$ of the sample expressed by eq. (10):

$$
\frac{1}{Z_{\mathrm{s}}(\omega)}=\frac{1}{R(\omega)}+j \omega C(\omega) \text {. }
$$

The complex electrical conductivity s of the sample is a difference of two terms:

$$
\sigma=\sigma^{\prime}-j \sigma^{\prime \prime},
$$

where $\sigma^{\prime}$ is the real and $\sigma^{\prime \prime}$ is the imaginary component.

The analysis of electrical conductivity in oxide thin ûlms and nanostructures such as $\mathrm{TiO}_{2}$ nanotubes, which are wide-band-gap materials and could become highly conductive, is an important step toward application in electronics and optoelectronics.

In the case of n-type semiconductor $\mathrm{TiO}_{2}$ nanotubes, the conduction mechanisms are important, and one can notice that for this type of material no intrinsic relaxation phenomena occur. The dielectric permittivity representation becomes inadequate, while complex impedance and complex conductivity formalisms can be used, in order to distinguish between various extrinsic and intrinsic conduction mechanisms.

The Bode diagram of the complex electrical conductivity, real, imaginary parts and modulus are presented in figure 7.

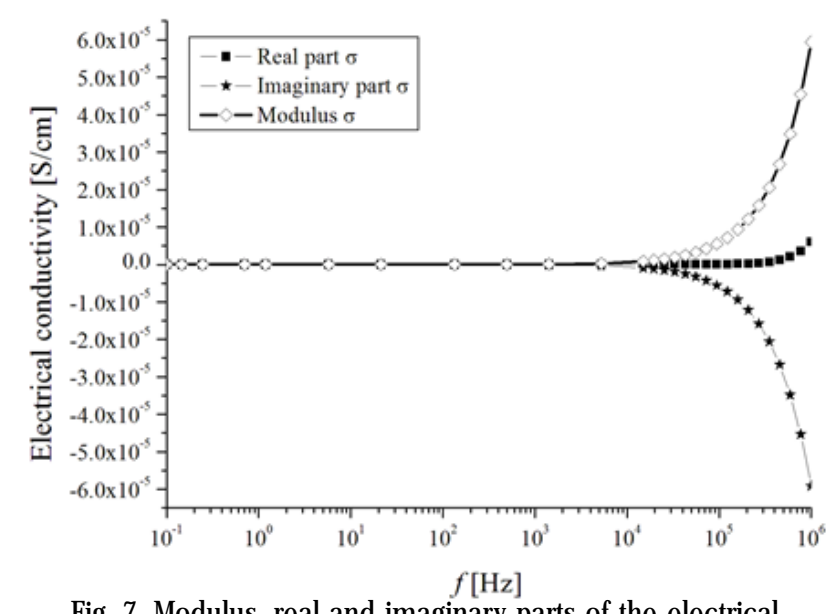

Fig. 7. Modulus, real and imaginary parts of the electrical conductivity versus frequency at room temperature

It can be observed that the modulus of the electrical conductivity increases with the frequency and it becomes of the order of $10^{-5} \mathrm{~S} / \mathrm{cm}$ in the $\mathrm{MHz}$ range. This is in perfect accordance with the semiconducting properties of this material, because by increasing the frequency, the capability of free electrons to flow from valence band to conduction band is accelerated, and thus the imaginary part of the electrical conductivity is predominant. Because the total impedance of the probe is smaller it can be concluded that, in the nanotube layer, the number of holes in the valence band increases. The upper part of the valence band is composed of $02 p$ states and the lower part of the conduction band of Ti $3 d$ states. According to [31], the oxygen vacancies and/or $\mathrm{Ti}^{3+} / \mathrm{Ti}^{4+}$ titanium interstitials, within the nanotubes walls, are one of conductivity sources for this type of material.

Recent studies present that another source for conductivity are the impurities [31]. The techniques for 


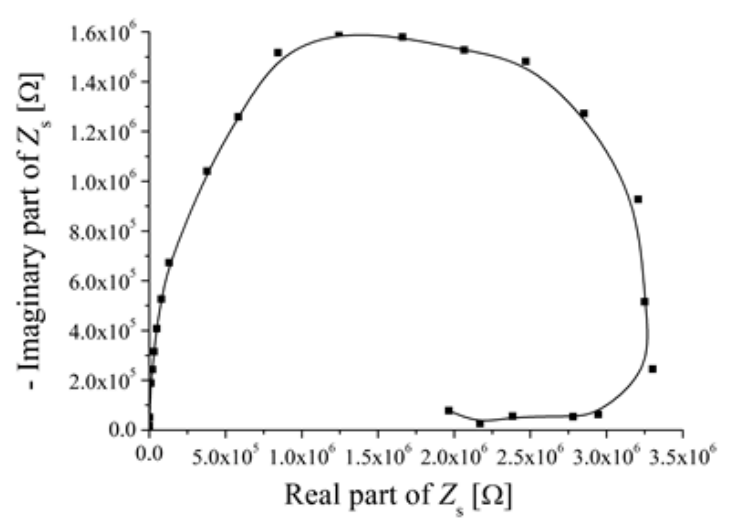

Fig. 8. Nyquist dependence of the self-organized $\mathrm{TiO}_{2}$ nanotubes at room temperature.

the development of $\mathrm{TiO}_{2}$ nanotubes structures introduce impurities through the primary sources or as contaminants. Impurities such as hydrogen, that are very difficult to be detected experimentally, are identified, even in an ultrahigh vacuum, in significant concentrations in oxide materials [31].

The displacement of the space charge, that is in phase with the electric field, can be described through the real part of the electrical conductivity $Z^{\prime}$, whereas the imaginary part Z" accounts for out-of-phase motion. Both the real and the imaginary parts of the complex conductivity depend on the frequency. The imaginary part of the complex conductivity represents a capacitive effect, which is very well showed in the Nyquist or Bode diagrams of the complex impedance (fig. 8 and fig. 9).

\section{Conclusions}

The electrochemical anodizing method was applied for the manufacturing of the $\mathrm{TiO}_{2}$ nanotubes growth on titanium, using a bio compatible electrolyte $\left(49.5 \mathrm{wt} \% \mathrm{H}_{2} \mathrm{O}\right.$ $-49.5 w t \%$ glycerol $-1 \mathrm{wt} \% \mathrm{HF}$ ). Electrical properties were investigated by means of the EIS and BDS impedance techniques. From the present results one can conclude:

The SEM analyses combined with the microscope program offer a very useful tool for the nanotube evaluation There were measured some important parameters of the tubes, which were used to compute a geometrical model of the $\mathrm{TiO}_{2}$ structure.

The electrical characterization shows the principal conduction mechanisms in this type of nano-materials. The material was analysed through electrical conductivity and impedance formalisms. The $n$ type conductivity, observed in the $\mathrm{TiO}_{2}$ nanotubes is due to the impurities and there are two types of conduction processes: electronic conduction and ionic conduction.

The Bode diagram of the electrical conductivity was correlated with the Bode and Nyquist diagram of the impedance. It was concluded that for frequencies in the range of $\mathrm{MHz}$, the material acts like a metallic conductor.

EIS investigation is also a useful tool to determine the impedance of nanomaterials and space charge layer capacitance at different values of the applied potentials.

\section{References}

1. GRIMES, C.A., MOR, G.K, $\mathrm{TiO}_{2}$ Nanotube Arrays - Synthesis, Properties and Applications, Springer Science \& Business Media, New York, 2009.

2. HU, M.Z., LAI, P., BHUIYAN, M.S, TSOURIS, C., GU, B., PARANTHAMAN, M.P., GABITTO, J., HARRISON, L., J. Mater. Sci., 44, no. 11, 2009, p. 2820-2827.

3. TSAI, C.C., TENG, H., J., Chem. Mater., 18, no. 2, 2006, p. 367-373.

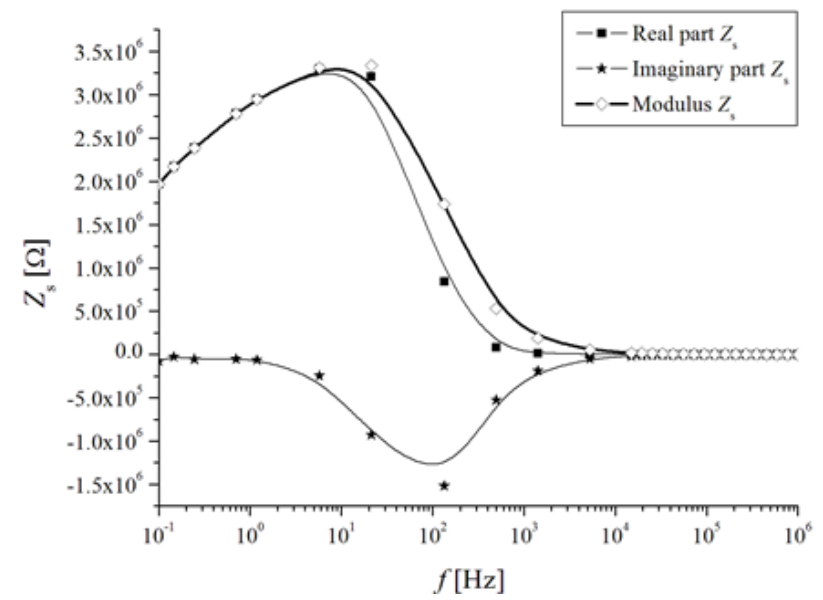

Fig. 9. Bode diagram of the real, imaginary parts and modulus of impedance as a function of the frequency determined through BDS.

4. LIU, Z., ZHANG, X., NISHIMOTO, S., IIN, M., TRYK, D.A., MURAKAMI, T., FUJISHIMA, A., J. Phys. Chem. C, 112, no. 1, 2008, p. 253-259.

5. PARK, H., KIM, H.G., CHOI, W.Y., Trans. Electr. Electron. Mater., 11, no. 3, 2010, p. 112-115.

6. TACCHINI, I., TERRADO, E., ANSON, A., MARTINEZ, M.T., J. Mater. Sci., 46, no. 7, 2011, p. 2097-2104.

7. HOYER, P., J. Langmuir, 12, no. 7, 1996, p. 1411-1413.

8. IMAI, H., TAKEI, Y., SHIMIZU, K., MATSUDA, M., HIRASHIMA, H., J. Mater. Chem., 9, no. 12, 1999, p. 2971-2972.

9. JUNG, J.H., KOBAYASHI, H., VAN BOMMEL, K.J.C., SHINKAI, S., SHIMIZU, T., J. Chem. Mater., 14, no. 4, 2002, p. 1445-1447.

10. MACWAN, D.P., DAVE, P.N., CHATURVEDI, S., J. Mater. Sci., 46, no. 11, 2011, p. 3669-3686.

11. BAVYKIN, D.V., PARMON, V.N., LAPKIN, A.A, WALSH, F.C., J . Mater. Chem., 14, no. 22, 2004, p. 3370-3377.

12. NIU, L., SHAO, M., WANG, S., LU, L., GAO, H., WANG, J., J. Mater. Sci., 43, no. 5, 2008, p. 1510-1514.

13. MACAK, J.M., TSUCHIYA, H., GHICOV, A., YASUDA, K., HAHN, R., BAUER, S., SCHMUKI, P., Curr. Opin. Solid State Mater. Sci., 11, no. 12, 2007, p. 3-18.

14. MORARU, A., MOREGA, A.M., PETRE, M., CILIANU, M., Rev. Roum. Sci. Techn. -Electrotechn. et Energ., 56, no. 2, 2011, p. 131-140.

15. PETRE, M., MOREGA, A.M., CILIANU, M., Rev. Roum. Sci. Techn. Electrotechn. et Energ., 57, no. 1, 2012, p. 30-39.

16. DUMITRIU, C., POPESCU, M., VOICU, G., DEMETRESCU, I., Rev. Chim. (Bucharest), 64, no. 6, 2013, p. 599-602.

17. ARSOV, L., FROEHLICHER, M., FROMENT, M., HUGOT-LE-GOFF, A., J. Chim. Phys, 72, 1975, p. 275-279.

18. RYU, W.H., PARK, C.J ., KWONG, H.S., J. Nanosci. Nanotechnol., 8, no. 10, 2008, p. 5467-5470.

19. PAULOSE, M., SHANKAR, K., YORIYA, S., PRAKASAM, H.E., VARGHESE, O.K., MOR, G.K., LATEMPA, T. ., FITZGERALD, A., GRIMES, C.A., J. Phys. Chem. B, 110, no. 33, 2006, p. 16179-16184.

20. NEUPANE, M.P., PARK, I.S., BAE, T.S., YI, H.K., WATARI, F., LEE, M.H., J. Electrochem. Soc., 158, no. 8, 2011, p. C242-C245.

21. XU, H.M., LIU, Y., WANG, H., ZHAO, W.X., HUANG, H., LIANG, C.L., YE, Q.H., LI, M., DENG, Y.J., SHEN, H., Adv. Mater. Res., 217-218, 2011, p. 1553-1558.

22. SU, Z., ZHOU, W., J. Mater. Chem., 21, no. 25, 2011, p. 8955-8970. 23. YASUDA, K., MACAK, J.M., BERGER, S., GHICOV, A., SCHMUKI, P., J. Electrochem. Soc., 154, no. 9, 2007, p. C472-C478.

24. YASUDA, K., SCHMUKI, P., Electrochim. Acta, 52, no. 12, 2007, p. 4053-4061.

25. GHICOV, A., TSUCHIYA, H., MACAK, J.M., SCHMUKI, P., Phys. Stat. Sol. A, 203, no. 4, 2006, p. R28-R30.

26. BERANEK, R., TSUCHIYA, H., SUGISHIMA, T., MACAK, J. M., TAVEIRA, L., FUJ IMOTO, S., KISCH, H., SCHMUKI, P., Appl. Phys. Lett., 87, no. 24, 2005, art. 243114. 
27. MACAK, J.M., GHICOV, A., HAHN, R., TSUCHIYA, H., SCHMUKI, P., J. Mater. Res., 2, no. 11, 2006, p. 2824-2828.

28. XIE, Y. B., Adv. Funct. Mater., 16, no. 14, 2006, p. 1823-1831.

29. TSUCHIYA, H., MACAK, J.M., GHICOV, A., RÄDER, S.A., TAVEIRA, L., SCHMUKI, P., Corros. Sci., 49, no. 1, 2007, p. 203-210.

30. TAVEIRA, L.V., SAGUES, A.A., MACAK, J.M., SCHMUKI, P., J. Electrochem. Soc., 155, no. 6, 2008, p. C293-C302.

31. JANOTTI, A., VARLEY, J.B., RINKE, P., UMEZAWA, N., KRESSE, G., VAN DE WALLE, C.G., Phys. Rev. B, 81, no. 8, 2010, art. 085212

32. PU, P., CACHET, H., SUTTER, E.M.M., Electrochim. Acta, 55, no. 20, 2010, p. 5938-5946.

33. POPESCU, S., MANOLE, C.C., PIRVU, C., Rev. Chim. (Bucharest), 64, no. 8, 2013, p. 796-802.

34. PAULOSE, M., SHANKAR, K., VARGHESE, O.K., MOR, G.K., HARDIN, B., GRIMES, C.A., Nanotechnology, 17, no. 5, 2006, p. 1446-1448.
35. MAN, I., PIRVU, C., DEMETRESCU, I., Rev. Chim. (Bucharest), 59, no. 6, 2008, p. 615-617.

36. KONTOS, A.G., KONTOS, A.I., TSOUKLERIS, D.S., LIKODIMOS, V., KUNZE, J., SCHMUKI, P., FALARAS, P., Nanotechnology, 20, no. 4, 2009, art 045603.

37. ALLAOUA, M.N., BOUNOUGHAZ, M., LAMARI, R., Rev. Chim. (Bucharest), 68, no. 2, 2017, p. 232-237.

38. GHERGHESCU, I.A., IONITA, D., CIUCA, S., DUMITRESCU, R.E., Rev. Chim. (Bucharest), 69, no. 1, 2018, p. 86-90.

39. MANESCU (PALTANEA), V., PALTANEA, G., POPOVICI, D., JIGA, G., AIP Conf. Proc., 1736, art. 020139 (2016).

40. RIKABI, A.A.K.K., BALABAN (CHELU), M., HARABOR, I., ALBU, P.C., SEGARCEANU, M., NECHIFOR, G., Rev. Chim. (Bucharest), 67, no. 9,2016, p. 1658-1665.

$\overline{\text { Manuscript received: } 13.04 .2018}$ 